\title{
ZNATI VIŠE A OSTVARIVATI MANJE: BEZBEDNOST KAO ASPEKT ODRŽIVOG URBANOG RAZVOJA BEOGRADA
}

\author{
Danica Stojiljković ${ }^{1}$, Vesela Radović ${ }^{2}$, \\ $\mathrm{UDK}=351.778 .5: 711.4(497.11)$ \\ Zorana Đorđević ${ }^{3}$ \\ https://doi.org/10.18485/fb_ubur.2018.1.ch21 \\ ${ }^{1}$ Institut za multidisciplinarna istraživanja, Univerzitet u Beogradu, \\ danica@imsi.rs \\ 2 Institut za multidisciplinarna istraživanja, Univerzitet u Beogradu, \\ veselaradovic@yahoo.com \\ ${ }^{3}$ Institut za multidisciplinarna istraživanja, Univerzitet u Beogradu, \\ zoranadjordjevic.arch@gmail.com
}

\section{Sažetak}

Pojam održivog razvoja u savremenom svetu eksploatiše se kao osnovni koncept opstanka civilizacije kakvu poznajemo. Shodno tome, tema bezbednosti i sigurnosti urbane sredine, kao ljudske potrebe za psihološkim blagostanjem, predstavlja važan segment kvaliteta urbanog života. Inicijative za urbanu bezbednost sastavni su deo aktuelnih tema globalizacije i integracije prostora, kao i pitanja koja se odnose na održivi razvoj, ograničenost i neefikasnost korišćenja prirodnih resursa i neadekvatne svesti o rizicima koje nose globalne klimatske promene. Akcioni plan Evropske unije u oblasti zaštite životne sredine posebno je označio potrebu za aktivnostima koje savremene gradove čine održivijim (European Action Programme to 2020).

Urbanizacija je oduvek sa sobom nosila rizike, koji su i danas prisutni na gotovo identičan način. Na primer, kvalitet vazduha zabrinjavao je stanovnike Londona u XVI veku na isti način kao i današnje stanovnike Beograda u kojem su kompetentne agencije kvalitet vazduha klasifikovale u najlošiju kategoriju na osnovu usvojenih regulatornih dokumenata. Veliki gradovi su složeni sistemi čiji pojedinačni delovi (podsistemi) mogu relativno lako i brzo postati uzrok sistemske neravnoteže. U takvim situacijama se postavlja pitanje stepena bezbednosti kao jedne od ključnih komponenti kvaliteta života i životnog prostora. Iako je prepoznata nužnost da bezbednosna politika bude inkorporirana u svaki deo procesa prostornog planiranja, beleži se značajan raskorak između znanja i veština i njihove primene u realnim okolnostima. Ključno pitanje je na koji način se u aktuelnom trenutku u izradi planskih dokumenata uključuje rizik od različitih opasnosti koje prete održivosti urbanog sistema. Takvi rizici su mnogobrojni i različiti počev od epidemija, požara, različtih oblika društvenih sukoba, i drugih. U analizama urbanih sredina važno je posebno razmotriti elemente koji definišu urbanu sredinu (ulice, prolaze, zgrade, parkove, javne površine), kao i njihove tehničke elemente (transportni sistemi, osvetljenje, sistemi oglašavanja, kontrola pristupa, elemente prostorne orijentacije).

Rad je kreiran u cilju analize uticaja bezbednosnih faktora na urbani razvoj Beograda u različitim periodima njegovog rasta i razvoja. Urbanističke koncepcije razvijane u socijalističkom periodu bile su u značajnoj meri kompatibilne sa principima održivog razvoja 
(Sustainability and Socialism: Socio-ecological ideas in urbanization of New Belgrade, 2016), dok poslednje dve decenije tranzicionog perioda karakteriše haotičnost i po mnogim aspektima zabrinjavajuća urbana bezbednost, koja negativno utiče na blagostanje društva u celini. Jedan od uočenih rizika za održivi razvoj Beograda tokom 1990-ih i 2000-ih godina bila je nekontrolisana i bespravna gradnja, čije su posledice dugoročne. Institucije sistema osetile su se kao nemoćne, a široko eksploatisan pojam „političke volje“ predstavljao je opravdanje za nepostojanje adekvatnog rešenja kojim bi se sprečila bespravna gradnja.

Nažalost, ni aktuelna normativnopravna regulativa nije implementirana u praksi, tako da su nastavljeni zloupotreba javnih prostora, nepoštovanje bezbednosnih normativa gradnje i narušavanje kvaliteta života građana. Mnogobrojne izveštaje međunarodnih institucija i organizacija koji ukazuju na neodrživost takvih aktivnosti - donosioci odluka ne prihvataju sa adekvatnom pažnjom (The Global Risks Report 2016, WHO Collaborating Centre for Research on the Epidemiology of Disasters - CRED). Iz tog razloga, dešava se da su gubici u određenim vanrednim situacijama katastrofalni, uprkos činjenici da se u naučnoj i široj javnosti nikada nije više pisalo i govorilo o bezbednosti, niti postojalo toliko visokoškolskih ustanova, instituta, kao i nevladinih i drugih organizacija koji se njome bave.

Gotovo da se može zaključiti da je rast aktuelnosti pojma bezbednosti u naučnoj i široj javnosti obrnuto proporcionalan implementaciji osnovnih principa održivog razvoja u društvu u kojem živimo. Naučna i stručna javnost ostaje na marginama dešavanja, a urbani razvoj Beograda poslednje decenije karakteriše prodor privatnih investicija, neoliberalnog tržišta, formiranja novih urbanih zona na periferijama grada, komercijalizacija centra i urbana džentrifikacija pojedinih zona. Ovakav način donošenja odluka nužno vodi do naprezanja sistema do krajnjih granica.

Kroz istoriju su brojni slučajevi razaranja čitavih gradova u katastrofama. U svakom od primera može se zapaziti manji ili veći uticaj faktora nepoštovanja određenih urbanističkih propisa neophodnih za bezbednost stanovnika grada (od požara u Londonu 1666. godine, zemljotresa u Kobeu 1995. godine, uragana Katrine u Nju Orleansu nakon 2005, do nuklearne katastrofe u Fukušimi 2011. godine). Takođe treba imati u vidu i poplave koje su 2014. godine uništile Obrenovac, čija obnova još traje. Rad zastupa stav da je racionalno delovanje moguće ostvariti isključivo kroz razumevanje smisla pojave, procesa i stanja $\mathrm{u}$ istoriji urbanizacije grada koji utiče na ljudsku, a samim tim i nacionalnu bezbednost.

Stoga je sa aspekta bezbednosti razmotreno nekoliko ključnih tačaka iz istorije urbanog razvoja Beograda, kako bi se sagledale složene relacije između izgrađene sredine i moguće podesnije implementacije koncepta održivog razvoja, kao osnove budućeg opstanka. U ovim aktivnostima nužno je inicirati ulogu nauke i struke radi postizanja opšteg društvenog konsenzusa o bezbednosnim rizicima i pretnjama održivom razvoju (Annual Report of the Government Chief Scientific Advisers 2014). Pri tome je važno naglasiti da je nužno da donosioci odluka imaju na umu da je planiranje neizostavan deo procesa odluke ,zašto i kako nešto uraditi“, dok je istovremeno potrebno imati na umu i sve moguće prepreke u relizaciji odluke i njenim (kratkoročnim ili dugoročnim) posledicama na budući razvoj.

Dakle, rad otvara pitanje bezbednosnih faktora i pretnji održivom urbanom razvoju Beograda u različitim periodima njegovog rasta i razvoja, i to na primeru opštine Novi Beograd i opštine Grocka. Veliki gradovi su složeni sistemi čiji pojedinačni delovi (podsistemi) mogu 
relativno lako i brzo postati uzrok sistemske neravnoteže. Tada iskrsava pitanje stepena bezbednosti kao jedne od ključnih komponenti kvaliteta života i životnog prostora. Ujedno, bezbednost i sigurnost urbane sredine predstavljaju sastavni deo aktuelnih tema globalizacije, integracije prostora i održivog razvoja. Iako je zapažena nužnost da bezbednosna politika bude inkorporirana u svaki deo procesa prostornog planiranja, beleži se značajan raskorak između znanja i veština, i njihove primene u realnim okolnostima. S tog stanovišta, možemo sagledati razlike između planski projektovanih celina i nelegalnih, spontano nastalih naselja u Beogradu. U poslednje dve decenije urbani prostor Novog Beograda postao je $u$ procesu savremene reurbanizacije složeniji i integrativniji, čime se dokazala održivost otvorenog plana funkcionalnog grada koji se može adekvatno nositi sa promenjivim zahtevima razvoja. Nasuprot tome, u periodu kada se planski razvija opština Novi Beograd, eskalirala je nekontrolisana i bespravna gradnja na drugom kraju Beograda, u opštini Grocka, posebno u naselju Kaluđerica (1967-1986). Tokom poslednjih decenija bespravna gradnja je identifikovana kao rizik za održivi razvoj Beograda, a njene dugoročne posledice odrazile su se i na blagostanje društva u celini. Institucije sistema videle su se kao nemoćne, a usvojeni zakonski akti nisu implementirana u praksi, tako da je nastavljena zloupotreba javnih prostora, nepoštovanje bezbednosnih normativa gradnje i narušavanje kvaliteta života građana. Iz tog razloga, u radu se zastupa stav da je radi postizanja opšteg društvenog konsenzusa o bezbednosnim rizicima i pretnjama održivom razvoju grada važno da donosioci odluka imaju na umu da je planiranje neizostavan deo procesa odluke ,zašto i kako nešto uraditi“ i da je neophodno inicirati ulogu nauke i struke.

Ključne reči: održivi razvoj, urbana bezbednost, urbani razvoj Beograda

\section{Zahvalnica}

Ovaj rad je podržan od strane međunarodnog projekta COST CA15127 Action „Resilient Communication Services Protecting End-user Applications from Disaster-based Failures“ (RECODIS).

\section{Uvod}

Pojam održivog razvoja u savremenom svetu eksploatiše se kao osnovni koncept opstanka civilizacije kakvu poznajemo. Shodno tome, tema bezbednosti i sigurnosti urbane sredine, kao ljudske potrebe za psihološkim blagostanjem, predstavlja važan segment kvaliteta urbanog života. Inicijative za urbanu bezbednost sastavni su deo aktuelnih tema globalizacije i integracije prostora, kao i pitanja koja se odnose na održivi razvoj, ograničenost i neefikasnost korišćenja prirodnih resursa $i$ neadekvatne svesti o rizicima koje nose globalne klimatske promene. Akcioni plan Evropske unije u oblasti zaštite životne sredine posebno je označio potrebu za aktivnostima koje savremene gradove čine održivijim (European Action Programme to 2020$)$. 
Veliki gradovi su složeni sistemi čiji pojedinačni delovi (podsistemi) mogu relativno lako i brzo postati uzrok sistemske neravnoteže. U takvim situacijama postavlja se pitanje stepena bezbednosti, kao jedne od ključnih komponenti kvaliteta života i životnog prostora. Iako je uočena neophodnost da bezbednosna politika bude inkorporirana u svaki deo procesa prostornog planiranja, beleži se značajan raskorak između znanja i veština, i njihove primene u realnim okolnostima. Nepoštovanje urbanističkih propisa ugrožava bezbednost stanovnika grada, te je sa aspekta bezbednosti u analizama urbanih sredina važno razmotriti posebno elemente koji definišu urbanu sredinu (ulice, prolaze, zgrade, parkove, javne površine) i njihove tehničke elemente (transportni sistemi, osvetljenje, sistemi oglašavanja, kontrola pristupa, elemente prostorne orijentacije). Posledice nepoštovanja urbanističkih propisa neophodnih za bezbednost stanovnika grada pokazale su se kroz istoriju u brojnim slučajevima razaranja čitavih gradova u katastrofama (od požara u Londonu 1666. godine, zemljotresa u Kobeu 1995, uragana Katrine u Nju Orleansu nakon 2005, nuklearne katastrofe u Fukušimi 2011, do poplava u Obrenovcu 2014. godine).

U ovom radu postavlja se pitanje bezbednosnih faktora u pretnji održivom urbanom razvoju Beograda u različitim periodima njegovog rasta i razvoja. Urbanističke koncepcije razvijane u socijalističkom periodu u značajnoj meri su kompatibilne sa principima održivog razvoja (Ristić \& Stojiljković 2016), dok poslednje dve decenije tranzicionog perioda karakteriše haotičnost i u mnogim aspektima zabrinjavajuća urbana bezbednost, koja negativno utiče i na blagostanje društva u celini. Shodno tome, u radu su sagledana dva oprečna primera - planski urbanizam opštine Novi Beograd i problem bespravne gradnje u opštini Grockoj kako bi se sagledale složene relacije između izgrađene sredine i mogućnosti za implementaciju koncepta održivog razvoja, kao osnove opstanka.

Jedan od primećenih rizika za održivi razvoj Beograda tokom poslednjih decenija jeste nekontrolisana i bespravna gradnja, čije su posledice dugoročne. Institucije sistema videle su se kao nemoćne, a široko eksploatisan pojam ,,političke volje“ predstavljao je opravdanje za neiznalaženje adekvatnog rešenja kojim bi se sprečila bespravna gradnja. Nažalost, ni usvojeni zakonski akti nisu implementirani u praksi, tako da su nastavljeni zloupotreba javnih prostora, nepoštovanje bezbednosnih normativa gradnje i narušavanje kvaliteta života građana. U radu se zastupa stav da je racionalno delovanje moguće ostvariti isključivo kroz razumevanje smisla pojave, procesa i stanja u istoriji urbanizacije grada, što utiče na ljudsku, a samim tim i nacionalnu bezbednost.

\section{Pravo na zdravu i bezbednu životnu sredinu}

Sa stanovišta bezbednosti u procesu urbanizacije Beograda u periodu socijalizma i postsocijalističke tranzicije možemo zapaziti povoljne i nepovoljne aspekte urbane održivosti. Elementi urbane sredine utiču na sigurnost kako fizičku, tako i društvenu, ekonomsku, ali i uopšteno na zaštitu životne sredine. Inicijative „prava na 
grad“, kao deo kontrakulture koje su se pojavile 1970-ih godina, zalagale su se za uticaj fizičke strukture na socijalne odnose koje se stvaraju u gradskom okruženju (Harvey, 1990). Prema tom viđenju, gubitak osećaja udobnosti i dobrodošlice u javnom gradskom prostoru vodi nedostatku slobodnog kretanja, što je grubo kršenje ljudskih prava i potpuno je jednako nasilju na ulicama. Početkom 1970-ih godina, posle prevazilaženja egzistencijalnog minimuma, u socijalizmu je počelo da se postavlja pitanje kvaliteta života, kako u oblasti stanovanja, tako i ishrane, zdravlja, obrazovanja, slobodnog vremena. Rudi Supek pojam „kvalitet života“ pominje u vezi sa ekološkim problemima (Supek, 1978: 82):

Zato, kada je reč o ekološkim problemima održanja ljudske vrste, neophodno je uvesti ne samo minimalne uslove pod kojima je čovek sposoban da se održi, nego i pojam kvaliteta života, tj. izvesne humane i estetske kriterijume života po kojima se čovek u načinu svoga života uzdiže iznad čisto biološke sfere životarenja.

Industrijski razvoj izražen u posleratnom periodu socijalizma bio je zasnivan na iluziji o neograničenom rastu, što je bilo shvaćeno kao sloboda neobuzdane i stihijske eksplotacije prirodnih dobara i sirovina, ne vodeći računa o mogućim posledicama i štetama koje se akumuliraju na duži period. Usled sve intenzivnijeg globalnog procesa urbanizacije i industrijalizacije u periodu 1970-ih godina postao je aktuelan koncept održivog razvoja, koji je naglasio složene veze između životne sredine i razvoja. Pojam održivog razvoja kao osnovnog koncepta u zaštiti životne sredine može se primetiti i pre njegovog zvaničnog nastanka. Gifford Pinchot je 1947. u SAD definisao potrebu očuvanja ,prirodnih resursa za najveće dobro, najvećeg broja ljudi, u što dužem vremenskom periodu“ (Merchant, 2011). Prirodni ili ekološki uslovi i procesi ne deluju odvojeno od društvenih procesa, pa su stoga zatečeni društveni i prirodni uslovi uvek rezultat složene transformacije trenutnih konfiguracija, koje su same po sebi i prirodne i društvene.

Nastojeći da na nacionalnom planu afirmiše načela međunarodnih dokumenata, a pre svega Deklaracije Ujedinjenih nacija o čovekovoj sredini, SFRJ je 1974. godine ustanovila ustavno pravo čoveka na zdravu životnu sredinu. To je prvi ustav u svetu koji je sadržao novo individualno pravo čoveka na zdravu životnu sredinu, gde se ističe da socijalističko društvo ,obezbeđuje uslove i unapređivanje prirodnih i drugih vrednosti čovekove sredine koje su od interesa za zdrav, siguran i delotvoran život i rad sadašnjih i budućih generacija“ (Marković, 1986: 133). Ukoliko se to uporedi sa navodima izveštaja Gro Harlem Brundland iz 1987. godine, gde se održivi razvoj definiše kao razvoj koji zadovoljava potrebe sadašnje generacije, ne ugrožavajući pritom budućnost sledećih generacija, može se uočiti progresivnost tadašnjih ekoloških stavova u jugoslovenskoj sredini.

Savremene zakonske regulative pokazuju da je Republika Srbija 2004. godine donela određeni broj tzv. ,ekoloških zakona“: Zakon o zaštiti životne sredine, Zakon o proceni uticaja na životnu sredinu, Zakon o strateškoj proceni uticaja na životnu sredinu i Zakon o integrisanom sprečavanju i kontroli zagađivanja životne sredine, čime se opredelila za implementaciju koncepta održivog razvoja (Radović, 
2013). To je potvrđeno i u nedugo zatim usvojenoj Nacionalnoj strategiji održivog razvoja (2008), kao i u Strategiji razvoja Grada Beograda (2011).

\section{Planski urbanizam Novog Beograda}

U periodu socijalizma najveći planski projekat u Beogradu bila je izgradnja Novog Beograda. Opština Novi Beograd osnovana je 1952. godine, a od tada se beleži njen konstantni rast. Ona se prostire na površini od 4.096 hektara i prema podacima iz poslednjeg popisa ima 214.506 stanovnika. Parametre održivog razvoja možemo sagledati u urbanističkoj postavci Novog Beograda, koja je projektovana pre nego što je termin održivog razvoja definisan na globalnom nivou. Iako je planiran kao novi administrativni centar, rađen po principima Atinske povelje (Le Corbusier, 1965) i funkcionalističkog urbanizma, Novi Beograd je u periodu socijalizma izgrađen samo kao monofunkcionalni prostor namenjen kolektivnom stanovanju.

Ideje funkcionalističkog grada mogu se povezati sa konceptom održivosti i bezbednosti životne sredine, imajući u vidu da je Le Korbizje nastojao da načini održivi spoj između prirode unutar koje se nalazi grad i samog grada. Odbacujući koncept klasične ulice, koja generiše buku, prašinu i škodljive gasove, okosnicu ideje funkcionalističkog grada predstavljali su slobodnostojeći objekti, koji omogućavaju ogromne gustine naseljenosti, pri tom okruženi parkovima i širokim zelenim površinama. Prema različitim analizama ekonomskih, ekoloških i socijalnih aspekata glavni ciljevi koncepta održivog urbanog razvoja jesu urbane forme koje utiču na smanjenje potrošnje energije, zagađenja životne sredine i korišćenja automobila, a podstiču razvoj javnog gradskog saobraćaja, pešačenja i korišćenje bicikala.

$\mathrm{Na}$ primeru planiranja i izgradnje Novog Beograda ispoljava se tendencija da se stvori humanije okruženje kroz viziju novog, čistog i zdravog grada. Tokom 1960-ih godina sazrevala je svest o neophodnosti intenzivnog uređenja naselja, što je uslovilo nastajanje širokog raspona zelenih pejzaža u zonama stanovanja i rekreacije na području Novog Beograda. Projektovan je veliki broj zelenih površina u sklopu novih stambenih naselja - uređeni sistemi staza, parkinga, pjaceta i mesta za odmor u zajednici sa igralištima i zelenilom oblikovanim u geometrijskom ili slobodnom stilu (Milićević-Nikolić, 1969).

Iako je u principima funkcionalističkog urbanizma očigledno postojanje ekološke svesti, tokom 1960-ih godina pojavljuju se brojne kritike usmerene prvenstveno na monofunkcionalno zoniranje. Ubrzo posle realizacije prvih blokova na Novom Beogradu, kritički stav je ovu naseobinu definisao kao „spavaonicu Beograda“, tehnokratsku urbanističku tvorevinu, suviše doslovnu transpoziciju ideja Le Korbizjea, naselje bez duha i identiteta, u kojem je teško orijentisati se usled uniformnog izgleda bloka i ortogonalnog rastera širokih ulica. Leon Krijer kritikuje modernistički urbanizam tvrdeći da je monofunkcionalno zoniranje ,antiekološko“, jer vodi nepotrebnoj potrošnji vremena, energije i zemljišta (Krier, 2009).

Ujedno, i Miloš Perović je izneo kritiku funkcionalističkog urbanizma Novog Beograda, navodeći kako jednom postavljeni ciljevi razvoja centralnih aktiv- 
nosti Novog Beograda ne bi trebalo da ostanu trajne vrednosti, već da bi one trebalo da zavise od funkcije društvenog, ekonomskog i kulturnog razvoja, tako da urbana struktura Novog Beograda ne bude konačni ishod, već deo kontinuiranog i održivog procesa planiranja (Perović, 1985). Sa stanovišta bezbednosti osnovna preporuka je izbegavanje monofunkcionalnih prostora, s obzirom na to da oni ne mogu pružiti angažovani prostor tokom 24 sata. Kako bi se oblikovala sigurna sredina, potrebno je angažovati prostor i učiniti ga atraktivnim različitim funkcijama kombinacijom stanovanja, javnih namena, poslovanja, komercijalnih delatnosti itd. (Planning System and Crime Prevention \& Secured by Design Principles - Concept, 2004). Tako, istraživanje o rizicima i bezbednostima u susedstvu potvrdilo je viši stepen percepcije rizika i osećaja nebezbednosti u novobeogradskom Bloku 45, koji je pretežno u funkciji stanovanja. Međutim, ovo istraživanje nije ukazalo da prostorno oblikovanje Bloka 45 ima bilo kakve direktne negativne efekte na osećaja sigurnosti i bezbednosti (Tomanović i Petrović, 2006).

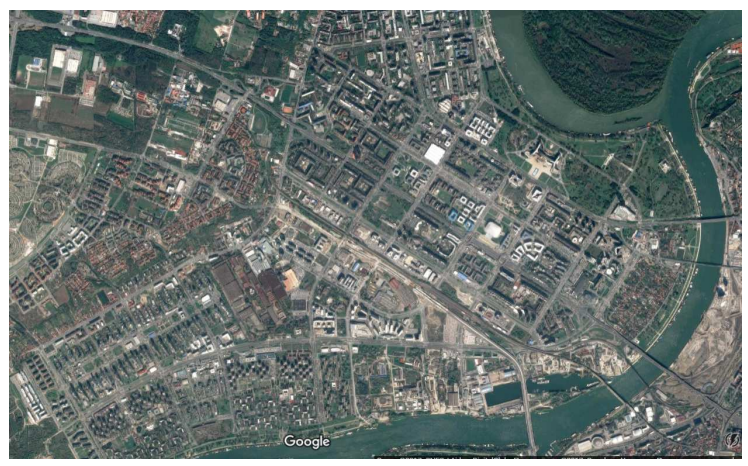

Slika 1. Ortofoto opštine Novi Beograd

U poslednje dve decenije Novi Beograd prolazi proces savremene reurbanizacije, koja ima značajan uticaj na fragmentaciju ljudskih potreba (stanovanje, rad, slobodno vreme), a samim tim na strukturu korisnika i kvaliteta života u Novom Beogradu. S obzirom na dobru komunalnu infrastrukturu i poziciju u odnosu na centar grada, Novi Beograd postaje izuzetno pogodan za investicije privatnog sektora, što je u periodu tranzicije omogućilo da se dotadašnja urbana struktura postepeno menja u pravcu glavnog komercijalnog centra. Dolazi do promene karaktera Novog Beograda, koji je od rezidencijalne zone postao glavna zona komercijalnog i poslovnog razvoja Beograda.

Kako se ističe u Generalnom urbanističkom planu Beograda 2021, područje centralne zone Novog Beograda planira se kao novi poslovno-trgovački, administrativni i kulturni centar državnog i regionalnog značaja (Generalni plan Beograda 2021). Sa aspekta urbane bezbednosti kompleksnost funkcija ima pozitivan uticaj na svakodnevni kulturni, socijalni i ekonomski život Novog Beograda. Komplementarnost novih funkcija i održiv saobraćaj funkcionalističkog urbanizma učinili 
su da urbani prostor Novog Beograda postane složeniji i integrativniji, čime se dokazuje održivost otvorenog plana funkcionalnog grada. U tom smislu se u današnjem trenutku Novi Beograd može postaviti u kontekst bezbedne i održive urbane sredine, koja je pokazala kako je dovoljno vitalna da se može nositi sa izmenjivim zahtevima razvoja i da je dovoljno fleksibilna da evoluira. Prednosti Novog Beograda - kvalitet i količina sunca, vazduha i zelenila, solidna tehnička oprema, saobraćajna funkcionalnost, efikasnost i racionalnost industrijske stambene izgradnje omogućile su da ovaj prostor danas predstavlja glavni fokus izgradnje na regionalnom nivou.

\section{Problem bespravne gradnje u opštini Grocka}

Beogradska opština Grocka ima površinu $300 \mathrm{~km}^{2}$ i u njoj živi 85.654 stanovnika. Kaluđerica je najveće od 15 naselja Grocke, klasifikovano kao urbano, u kojem, prema podacima iz poslednjeg popisa, živi 27.362 stanovnika. Kaluđerica se kvalifikuje kao primer naselja u kojem se ogledaju dugoročne posledice nekontrolisane i bespravne gradnje u Gradu Beogradu. Državni organi nisu činili bezmalo ništa da se nastanak ovakvog naselja spreči legalnim merama.

U Republici Srbiji bilo je mnogo različitih razloga za pojavu bespravne gradnje. Ovaj fenomen, koji se javlja sa porastom broja stanovnika u gradovima, usled stambene politike koja nije na odgovarajući način pratila nesklad između industrijalizacije i urbanizacije. Bespravna gradnja je ,stihijski proces u kome se planski uticaj pojavljuje tek u fazi sanacije, a ostali elementi urbane politike deluju takođe sa zakašnjenjem ili represivno“ (Saveljić, 1988: 167). U periodu 1946-1981. u Beograd i okolinu se doselilo oko 580.000 ljudi, godišnje prosečno po 18.000 stanovnika (Saveljić, 1988: 25).

Kaluđerica je jedno od najvećih divljih naselja u Evropi. Karakterišu je kuće različitih oblika, spratnosti i kvaliteta gradnje, izgrađene bez urbanističkog plana, a u velikom broju slučajeva i bez arhitektonskog projekta. Usled hronične krize stambenog prostora u Jugoslaviji, nepoštovanja pravne regulative i loših međusobnih odnosa MZ Kaluđerica i SO Grocka, bespravna gradnja u Kaluđerici eskalirala je u periodu 1967-1986. godine. Od 1967. godine počela je intenzivna stambena gradnja, koja je sve više uzimala maha, da bi 1976-1980. dostigla vrhunac. Tada je započeta izgradnja $40 \%$ objekata.

Kaluđerica je od sela sa 200 pretežno poljoprivrednih domaćinstava do 1987. godine izrasla u naselje sa oko 7.000 domaćinstava. Usled stihijske gradnje i doseljavanja mladog stanovništva, došlo je do napuštanja poljoprivrede, koja je do 1961. imala vodeću ulogu i zapošljavala 82,8\% stanovništva (Saveljić, 1988, 51). Iako je 1979. godine usvojen Detaljan urbanistički plan stambenog naselja Kaluđerica, nastavljeno je sa uknjižavanjem pojedinih placeva i objekata zbog ,tolerantnosti“ nadležnih organa, što je samo povećalo bespravnu gradnju (Saveljić, 1988: $169)$. 


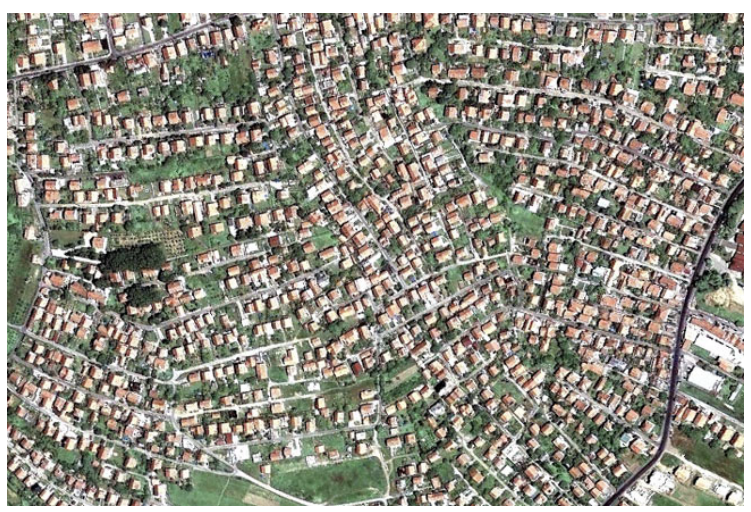

Slika. 2. Ortofoto naselja Kaluđerica, opština Grocka

S obzirom na to da bespravna gradnja ne podrazumeva poštovanje urbanističkog projekta, parcelacija zemljišta je bila neplanska. Gradnja se realizovala uglavnom bez arhitektonskog projekta (Saveljić, 1988: 170), usled čega su načinjene nepopravljive greške. Iz tog razloga je, između ostalog, i pozicioniranje objekata na parceli i prostorna organizacija samih objekata bila neplanska. Utvrđeno je da je čak jedna trećina bespravnih objekata nedovoljno ili pak uopšte nije osunčana.

Takođe, većina objekata je spratnosti prizemlje i jedan sprat, ili prizemlje, sprat i potkrovlje, te dve trećine objekata imaju više od jednog stana. Dakle, po objektu ima više od jednog domaćinstva koje nema obezbeđene osnovne uslove za zdrav život. Ovakav način gradnje nepovoljno je uticao na formiranje saobraćajnica, koje nisu odgovarajuće širine, preglednosti i međusobne umreženosti. Pešačkih komunikacija gotovo da nema, kao ni javnih površina - parkova, skverova, drvoreda i sličnih prostora.

Neadekvatna primarna infrastruktura u naselju Kaluđerica imala je značajan uticaj na zdravlje stanovništva. Krajem 1980-ih godina nijedan bespravan objekat nije imao sve komunalne instalacije, a čak $8 \%$ je bilo bez ikakve komunalne opreme (čak i bez poljskog toaleta i bilo kakvog vida grejanja). Građene su jeftine poniruće septičke jame sa vodopropusnim zidovima, koji ugrožavaju kvalitet vode u bunarima. Usled bakteriološke kontaminacije zemljišta fekalnim i otpadnim vodama, neadekvatnog vodosnabdevanja iz individualnih bunara (iz kojih je u $90 \%$ slučajeva uzorak bakteriološki neispravan), u istoriji naselja dolazilo je do pojava crevnih bolesti, varičela, rubeola, paratitisa, hepatitisa, morbila, šarlaha... Godine 1983/1984. bila je velika epidemija zarazne žutice u opštini Grocka, a naročito su se u Kaluđerici stvorila endemska žarišta - stalno je prisustvo ove bolesti zbog loših sanitarno-higijenskih uslova (Saveljić, 1988: 151).

U izveštaju Kvalitet životne sredine grada Beograda u 2012. godini (2013: 336), ističe se da „MZ Kaluđerica u pogledu ugrožavanja životne sredine i dalje predstavlja poseban problem, sa nelegalnom infrastrukturom i divljim kanalizacionim mrežama, kod kojih često dolazi do zagušenja i izlivanja otpadnih voda, kao i 
stanje Kaluđeričkog potoka (koji se uliva u Bolečicu)“. U kontekstu ekološke bezbednosti, a posebno u oblasti zdravlja stanovništva, naselje Kaluđerica predstavlja stalni epidemiološki rizik i pretnju celom Beogradu, zbog mnogobrojnih nerešenih infrastrukturnih problema. Ipak, u jedinoj zdravstvenoj ustanovi u Grockoj nema epidemiologa, koji postoji u pet drugih beogradskih opština: Novi Beograd, Voždovac, Lazarevac, Obrenovac i Palilula.

U toku 2016. godine započeta je izgradnja kanalizacione mreže u naselju Kaluđerica, a u okviru tzv. kapitalnih projekata predviđenih u gradskoj opštini Grocka i pomoći izvršne vlasti Grada Beograda (Izgradnja kanalizacione mreže u Kaluđerici). Planom aktivnosti predviđena su neophodna sredstva, a deo sredstava u svrhu upravljanja otpadnim vodama predviđen je i budžetima opštine Grocka (u periodu od 2015. do 2018. godine). Prikaz planiranih sredstava pruža se u Tabeli 1.

\begin{tabular}{|l|c|c|c|}
\hline $\begin{array}{l}\text { Infrastrukturni } \\
\text { sistem }\end{array}$ & $\begin{array}{l}\text { Planirana sredstva } \\
\text { u 2016. godini } \\
(104 €)\end{array}$ & $\begin{array}{l}\text { Planirana sredstva } \\
\text { u 2017-2025. } \\
\text { godini }(104 €)\end{array}$ & $\begin{array}{l}\text { Ukupno potrebna } \\
\text { sredstva (104 } €)\end{array}$ \\
\hline $\begin{array}{l}\text { Sistem } \\
\text { vodosnabdevanja }\end{array}$ & 4,30 & 31,14 & 35,44 \\
\cline { 2 - 4 } $\begin{array}{l}\text { Kanalizacioni } \\
\text { sistem }\end{array}$ & $/$ & 33,30 & 33,30 \\
\cline { 2 - 4 } $\begin{array}{l}\text { Ukupno vodovod } \\
\text { i kanalizacija }\end{array}$ & 4,30 & 64,44 & 68,74 \\
\cline { 2 - 4 }
\end{tabular}

Tabela. 1. Rekapitulacija procenjenih troškova razvoja vodovodne i kanalizacione mreže za opštinu Grocka, izvor: Plan razvoja vodovodnog i kanalizacionog sistema na području opštine Grocka - period realizacije 2016-2025, mart 2016.

Dakle, gotovo 50 godina nakon početka bujanja bespravne gradnje u naselju Kaluđerica započinje se sa rešavanjem krucijalnog problema izgradnje primarne infrastrukture. Bez obzira na aktuelne napore da se ublaže posledice bespravnog načina gradnje mnogim naknadnim aktivnostima gradske i opštinske vlasti, jasno je da se naselje Kaluđerica ne može oceniti kao primer zdrave, bezbedne i održive urbane sredine.

Sredinom XX veka Kaluđerica je bila prostor povoljnih lokacijskih i ekoloških kvaliteta, koji se usled guste bespravne gradnje pretvorio u teško rešiv problem celog Beograda. Nakon višedecenijskog zapostavljanja problema bespravne gradnje evolucija ovog naselja u najvećoj meri svodi se na sanaciju posledica neplanskog razvoja.

\section{Diskusija i zaključak}

Ukoliko se kao jedan od osnovnih ciljeva savremenog urbanističkog planiranja postavi obezbeđivanje visokog kvaliteta bezbednosti i održivosti urbanih celina, onda je nužno da bezbednost zajednice postane integralni deo planskog dokumenta, te da 
postanu prioritetni planovi i projekti koji uzimaju u obzir zdravlje stanovništva, prevenciju kriminala i bezbednost zajednice (Safer Places - The Planning System and Crime Prevention \& Secured by Design Principles - Concept, 2004). Ovo je od suštinske važnosti za kvalitet urbanog života, jer postoji direktna veza između urbane bezbednosti i stabilne zajednice. Ključno pitanje je na koji način se u aktuelnom trenutku u izradi planskih dokumenata uključuje rizik od različitih opasnosti koje prete održivosti urbanog sistema - počev od epidemija, požara, različtih oblika društvenih sukoba i drugih. Uvođenjem opšteg standarda bezbednosti u planiranje olakšava se prirodno nadgledanje i stvara se osećaj vlasništva i odgovornosti za svaki deo planiranog razvoja.

Iako je garancija ustavnog prava na zdravu i bezbednu životnu sredinu (Ustav SFRJ iz 1974) bila napredna i dalekovida, u istom vremenskom rasponu druge polovine XX veka na teritoriji Beograda razvile su se dve opštine - Novi Beograd, koji je u potpunosti omogućavao svojim stanovnicima pravo na zdravu i bezbednu životnu sredinu, i opština Grocka, odnosno naselje Kaluđerica, u kojoj je ovo pravo kršeno do krajnjih granica ljudskog dostojanstva, usled bespravne, neplanske gradnje. Globalizacija, kao i postsocijalistička transformacija istočnog blo$\mathrm{ka}$, bitno je uticala na promenu strukture, funkcije i forme savremenih gradova (Vujović i Petrović, 2005).

Područje Novog Beograda je u periodu socijalizma predstavljalo pasivno, neizgrađeno prostranstvo. U poslednje dve decenije racionalno planirani i projektovani novobeogradski blokovi privlače najveću pažnju investicija, čime se doprinosi dugoročnoj i odgovornoj uporebi resursâ Beograda. Tako je Novi Beograd postao primer bezbedne i održive urbane sredine, koja je dovoljno fleksibilna da prati savremene zahteve razvoja gradskog života.

Nasuprot tome, u opštini Grockoj i njenom naselju Kaluđerici posledice višedecenijske bespravne gradnje i danas predstavljaju ozbiljnu prepreku u razvoju ne samo ovog dela, već grada u celini. Izveštaje međunarodnih institucija i organizacija koji ukazuju na neodrživost neplanskih naselja donosioci odluka ne prihvataju sa adekvatnom pažnjom (The Global Risks Report 2016, WHO Collaborating Centre for Research on the Epidemiology of Disasters - CRED), te dolazi do fenomena da znamo osetno više nego što u praksi ostvarujemo. Upravo iz tog razloga dešava se da su gubici u određenim vanrednim situacijama katastrofalni, uprkos činjenici da se u naučnoj i široj javnosti nikada nije više pisalo i govorilo o bezbednosti, niti postojalo toliko visokoškolskih ustanova, instituta, kao i nevladinih i drugih organizacija koji se njome bave.

Naučna i stručna javnost ostaje na marginama zbivanja, a urbani razvoj Beograda poslednje decenije karakteriše prodor privatnih investicija, neoliberalnog tržišta, formiranja novih urbanih zona na periferijama grada, komercijalizacija centra i urbana džentrifikacija pojedinih zona. Ovakav način donošenja odluka nužno vodi do naprezanja sistema do krajnjih granica. Stoga je u urbanističkom planiranju neophodno inicirati ulogu nauke i struke radi postizanja opšteg društvenog konsenzusa o bezbednosnim rizicima i pretnjama održivom razvoju (Annual Report of the Government Chief Scientific Advisers 2014). Pritom je važno da donosioci odluka 
imaju na umu da je planiranje neizostavan deo procesa odluke „zašto i kako nešto uraditi“, dok je istovremeno potrebno anticipirati i sve moguće prepreke u realizaciji odluke i njenim (kratkoročnim ili dugoročnim) posledicama na budući razvoj.

\section{Literatura}

1. European Commission. European Action Programme to 2020. 7th EAC. http://ec.europa.eu/environment/action-programme/

2. Generalni plan Beograda 2021, Službeni list Grada Beograda, br. 27/2003, 25/2005, $34 / 2007$.

3. Government Office for Science. Annual Report of the Government Chief Scientific Advisers 2014. Innovation: managing risk not avoiding it.

4. Harvey, D.: The Condition of Postmodernity: An Enquiry into the Origins of Cultural Change, Blackwell Publishing, 1990.

5. https://www.gov.uk/government/uploads/system/uploads/attachment_data/file/3819 06/14-1190b-innovation-managing-risk-evidence.pdf (5. 3. 2017).

6. Kvalitet životne sredine grada Beograda u 2012. godini, Sekretarijat za zaštitu životne sredine, Gradski zavod za javno zdravlje, Regional Environmental Center, Beograd 2013.

7. Krier, L.: The Architecture of Community, Island Press, London/Washington 2009.

8. Le Corbusier: Atinska povelja, Klub mladih arhitekata, Beograd 1965.

9. Marković, D.: Socijalna ekologija, Zavod za udžbenike i nastavna sredstva, Beograd 1986.

10. Merchant, C. (ed.): Major Problems in American Environmental History, Wadsworth Publishing Company, 2011.

11. Milićević-Nikolić, O.: 'Dileme o stvaralaštvu vrtne arhitekture u stambenim naseljima u Beogradu'. Arhitektura urbanizam, 56-57, 110-115, 1969.

12. Nacionalna strategija održivog razvoja, Službeni glasnik RS, 57/08, 2008.

13. Office of the Deputy Prime Minister \& Home Office: Safer Places - The Planning System and Crime Prevention \& Secured by Design Principles - Concept; London, 2004.

14. Perović, M.: Iskustva prošlosti, Građevinska knjiga, Beograd, 1985.

15. Plan razvoja vodovodnog i kanalizacionog sistema na području opštine Grocka period realizacije 2016-2025, Direkcija za građevinsko zemljište i izgradnju Beograda, JP i Beogradski vodovod i kanalizacija, mart 2016, www.beoland.com

16. Radović, V.: Bezbednost životne sredine: evolucija i savremeni pristupi, Univerzitet Educons, Fakultet za primenjenu bezbednost, Novi Sad 2013.

17. Ristić Trajković, J., Stojiljković, D.: 'Sustainability and Socialism: Socio-ecological ideas in urbanization of New Belgrade', Facta universitatis - series: Architecture and Civil Engineering, vol. 14, br. 3, 343-353, 2016.

18. Saveljić, B.: Beogradska favela - Nastanak i razvoj Kaluđerice kao posledica bespravne stambene izgradnje u Beogradu, Istraživačko-izdavački centar SSO Srbije, 1988.

19. Strategija razvoja Grada Beograda, 2011.

20. Detaljni urbanistički plan stambenog naselja Kaluđerica, Službeni list Grada Beograda, br. 18/1979.

21. Supek, R.: Ova jedna zemlja, SNL, 1978.

22. The Global Climate Risk Index 2016. World Economic Forum - The Global Risks Report 2016, www.WorldRiskReport.org (Pristupljeno 13. 3. 2017.)

23. Tomanović, S., Petrović M.: 'Rizici i bezbednost u susedstvu iz perspektive dece i njihovih roditelja', u: Tomanović, S. (ur.): Društvo u previranju, ISI FF, Beograd 2006. 
24. Ustav Socijalističke Federativne Republike Jugoslavije, 1974.

25. Vujović, S., Petrović, M.: Urbana sociologija, Zavod za udžbenike i nastavna sredstva, Beograd 2005.

26. WHO Collaborating Centre for Research on the Epidemiology of Disasters - CRED, The Office of Foreign Disaster Assistance - OFDA, Université Catholique de Louvain, Emergency Events Database EM-DAT, http://www.emdat.be (Pristupljeno 2. 3. 2017.)

\section{KNOW MORE BUT ACHIEVE LESS: SECURITY AS THE ASPECT OF SUSTAINABLE URBAN DEVELOPMENT OF BELGRADE}

\section{Summary}

In the contemporary world, sustainable development is a basic concept of existence of the civilization we know. Therefore, as a human need for psychological welfare, security and safety of urban environment are an important part of the urban life quality. Urban security initiatives are a part of current subject, such as globalisation, integration of space and questions related to sustainable development, limitations and inefficient use of natural resources, and inadequate consciousness of risks deriving from global climate change. The action plan of the European Union in the field of environmental protection has specifically marked the need for activities that making contemporary cities more sustainable (European Action Programme to 2020). Urbanization has always has carried the risks that are identically present today. For example, the inhabitants of 16th century London were concerned about air quality the same way as the nowadays population of Belgrade, where competent agencies qualified the air quality in the lowest category according to adopted regulatory documents. Big cities are complex systems with many segments (subsystems) that relatively easily and quickly can cause unbalance of the system. In that case, the issue of security level is in question, as one of the key components of life quality and living space. Although the necessity for incorporating security policy in each part of urban planning, there is a significant gap between knowledge, skills, and their application in real circumstances. Key question is in what way the risk of various hazards that are threats to the sustainability of urban systems should be included in the planning documents. There are numerous and various risks - epidemics, fire, social conflicts, etc. In the analysis of urban environment it is important to specifically consider the elements that define the urban environment (streets, walkways, buildings, parks, public spaces), as well as their technical elements (transporting systems, lighting, advertising systems, access control, elements of the spatial orientation).

The goal of this paper is to analyse the impact of security factors on urban development of Belgrade in its various periods of growth and development. Urbanistic concepts developed in the socialist period were significantly compatible with the principles of sustainable development (Sustainability and Socialism: Socio-ecological ideas in urbanization of New 
Belgrade, 2016), while the last two decades of the transition period are chaotic with alarming urban security issues on many aspects, which negatively affects the well-being of society as a whole. One of the recognized risks for sustainable development of Belgrade during 1990s and 2000s was the uncontrolled and illegal building. It has a long term consequences. System institutions were powerless and widely used term of "political will" was the justification for non-existence of appropriate solution that would prevent illegal building. Unfortunately, the current normative-legal regulation is not implemented in practice, so the misuse of public space, disregard of security norms for construction and violation of citizens' life quality are continued. Decision makers do not consider with adequate attention numerous reports of international institutions and organizations that point out the unsustainability of such activities (The Global Risks Report 2016, WHO Collaborating Centre for Research on the Epidemiology of Disasters - CRED). Therefore, the loss in emergencies are often catastrophic, despite the growing number of writings and talks on the security issues in public and scientific circles, as well as the numerous faculties, institutes, nongovernmental and other organization dealing with the subject. We can conclude that the growth of popularity of the term security in scientific and wider public is reciprocal to implementation of fundamental principles of sustainable development in society we live in. Scientific and professional community remains on the margins of events, so the urban development of Belgrade in the last decade is characterized by breakthrough of private investment, neoliberal market, the establishment of new urban areas on the outskirts of the city, the commercialization of the city and urban gentrification of particular zones. This kind of decision-making inevitably leads to stressing the system to its final limit.

Entire cities were devastated through history. In each example, we recognize the impact of not following the urban regulations that are necessary for the security of inhabitants (from the fire in London 1666, earthquake in Kobe 1995, Hurricane Katrina in New Orleans after 2005, to the nuclear catastrophe in Fukushima 2011). There are also the floods that devastated Obrenovac in 2014 that renewal is still going on. The paper stressed that the rational action is possible only through the understanding the sense of phenomena, processes and states in the history of the city that affects human, and thus national security. Therefore, from the security aspect we discussed several key points in the history of urban development of Belgrade, in order to comprehend the complex relations between the built environment and possible adequate implementation of the concept of sustainable development as the basis for future survival. In these activities, it is necessary to initiate the role of science and profession to achieve a general social consensus on security risks and threats to sustainable development (Annual Report of the Government Chief Scientific Advisers 2014). It is important to emphasize that it is essential that decision-makers have in mind that planning is an integral part of the decision "why and how to do something," while it is necessary to bear in mind all possible obstacles in the implementation of the decision and its (short-term or long-term) consequences for future development.

Key words: sustainable development, urban security, urban development of Belgrade

\section{Acknowledgements}

This work was supported by the COST CA15127 Action "Resilient Communication Services Protecting End-user Applications from Disaster-based Failures” (RECODIS). 